BJHS: Themes 1: 249-266, 2016. C British Society for the History of Science 2016. This is an Open Access article, distributed under the terms of the Creative Commons Attribution licence (http://creativecommons.org/licenses/by/4.0/), which permits unrestricted re-use, distribution, and reproduction in any medium, provided the original work is properly cited.

doi:10.1017/bjt.2016.7 First published online 6 April 2016

\title{
The future arrives earlier in Palo Alto (but when it's high noon there, it's already tomorrow in Asia): a conversation about writing science fiction and reimagining histories of science and technology
}

\author{
ANNA GREENSPAN, * ANIL MENON, ${ }^{* *}$ KAVITA PHILIP $^{* * *}$ \\ AND JEFFREY WASSERSTROM
}

\begin{abstract}
A conversation between philosopher of digital cultures Anna Greenspan and historian of China Jeffrey Wasserstrom, speculative-fiction writer Anil Menon, and historian of science Kavita Philip, exploring the emerging work from scholars who have grown up with the global influence of science fiction in popular culture while being trained in the disciplinary spaces between science, engineering, social science, law and the humanities. The following questions are addressed: what are the prehistories of science fiction and the futures of such interdisciplinary work? How do India and China, as places where important new science fiction is being written, and as nations exploding now into emerging markets characterized by technological dynamism, fit into older historiographic frames that saw the European Enlightenment as the source of modern science, and the 'developing world' as destined only to ever play catch-up? How should the politics of digital futures and non-European pasts figure in historical research and in fiction writing, keeping in mind the historian's fear of presentism and anachronism, and the fiction writer's dislike of political moralism?
\end{abstract}

A new kind of work is emerging from scholars who have grown up with the global influence of science fiction in popular culture while being trained in the disciplinary spaces between science, engineering, social science, law and the humanities. What are the prehistories of science fiction and the futures of such interdisciplinary work? How do India and China, as places where important new science fiction is being written, and as nations exploding now into emerging markets characterized by technological dynamism, fit into older historiographic frames that saw the European Enlightenment as the source of

* New York University, Shanghai. Email: ag158@nyu.edu.

**Email: iam@anilmenon.com.

*** Murray Krieger Hall 300K, Mail Code 3275, University of California-Irvine, Irvine, CA 92697, United States. Email: kphilip@uci.edu.

$* * *$ History Department, 200 Krieger Hall, University of California-Irvine, Irvine, CA 92697-3275, United States. Email: jwassers@uci.edu. 
modern science, and the 'developing world' as destined only to ever play catch-up? How should the politics of digital futures and non-European pasts figure in historical research and in fiction writing, keeping in mind the historian's fear of presentism and anachronism, and the fiction writer's dislike of political moralism? Philosopher of digital cultures Anna Greenspan talks with historian of China Jeffrey Wasserstrom, speculative-fiction writer Anil Menon, and historian of science Kavita Philip.

Anna: Are China and India finally, undeniably, modern now? Are these 'alternative' modernities? Is it time to rethink the catch-up model of modernity, and if so, how?

Jeff: One dilemma of having to play 'catch-up' is that by the time you achieve a metric that was once important, it is seen as passé by some of those who bragged about it when they achieved the same thing. The 2010 Shanghai Expo is a great case in point. It was the biggest World's Fair in history, arguably the biggest planned event ever staged by human beings, yet seemed largely irrelevant to many people living in London (site of the granddaddy of all fairs, which was held in 1851), Paris (where many famed Universal Expositions were held) and also the United States, even though some Americans took great pride in Philadelphia hosting the 1876 World's Fair, which was not just the first held outside Europe but bigger than any that preceded it.

Of course, by now it is Olympics more than Expos that are major markers of global arrival, and China did 'catch up' in a way that caught the world's attention with the high-tech 2008 Games. We could see the Beijing Olympics as an example of something where China didn't simply become part of a game, so to speak, with pre-set rules, but, in the way it joined, altered the terrain. In the lead-up to the games, many people were asking 'how will the Olympics change China?' Anthropologist Susan Brownell, by contrast, suggested that we should also be musing on how China might change the Olympics. I think history has already proved her prescient: the Olympics since 2008 have been altered, in terms of the expectations for high-tech spectacle, being judged against what China did, perhaps even favouring, though not always, authoritarian settings that can guarantee certain kinds of predictability.

It is interesting to ponder more generally some ways that catching up and altering can merge, with a partially alternative modernity being the result. Two very different things that come to mind are Japan's entrance into the club of empire creators and Shanghai's emergence as the city with, arguably, the most globally famous skyline. It is common to see Japan as simply having been imitative with its empire, but historian and cultural theorist Prasenjit Duara has suggested in his work on Manchukuo that Tokyo's way of handling that space was as much a precursor of things to come as a last gasp of old ways of doing things. ${ }^{1}$ It could be seen as a clientalist state, rather than formal colony, of the sort we grew more used to in Cold War times (not that there weren't other early examples). And the capital city largely built from scratch may have been a throwback to something like St Petersburg and a precursor to places like Myanmar's Naypyidaw. Uncomfortable as this analogy surely is to Beijing, there are also some

1 Prasenjit Duara, Sovereignty and Authenticity: Manchukuo and the East Asian Modern, Lanham, MD: Rowman \& Littlefield Publishers, 2004. 
parallels between the sort of forced modernization that has been imposed on Tibet and Xinjiang since 1949 and the kind that was imposed on Manchuria during the 1930s.

As for Shanghai's skyline, in some ways it's competing to be seen as thoroughly modern, with tall buildings like those of other places. But this can seem very old-fashioned, and terms like 'retro-futuristic' and 'Jetson-like' have been applied to parts of Pudong from the beginning. There was even a double or triple echo of the past in efforts to present the Pearl of the Orient Tower, which looks a bit like an East Berlin building that pre-dates it, as Shanghai's answer to the Eiffel Tower (icon of an early Parisian World's Fair) - as in the early 1900s the Peace Hotel across the river was called the 'Eiffel Tower' of a 'Paris of the East' located in China. The Shanghai skyline could be the sole focus of a long essay on the themes we are addressing here, as so many things come together with it. It has been used in films (for example, Code 46) to represent times to come, and used at times to represent what a Western city will eventually look like (some of Her, set in an LA-to-be, used Pudong shots). In the 2010 World Expo, one thing that undermined the ability of the event to seem as futuristic as it might have was that, from the fairgrounds, you could see the SF-like Pudong buildings competing with what was on display in the World's Fair's pavilions. Similarly, the theme of foods of all parts of Italy and all parts of the world of the Milan 2015 Expo, which I also visited, competed with the Italian food scene beyond the grounds - we are far removed from the days when a kick of a World's Fair was being able to eat a food from a different country or even continent. On the other hand, the low-rise and not particularly futuristic looking cityscape near the Milan fairgrounds did not undermine the futuristic claims of the 2015 Expo.

There are other cities that are trying to copy Shanghai objects, and there were some genuinely futuristic moves made in the city, such as bringing the first magnetic levitation train to Pudong. And the way that Shanghai presents itself as a re-globalizing metropolis, which is especially well suited to be modern in the twenty-first century because it had an earlier golden era of cosmopolitan modernity, is something that has been and might be copied by other places. I guess this is a roundabout way of saying that one kind of alternative modernity comes into being when different local and imported versions of the modern are mashed together in a single place.

Kavita: There was an amusing moment last year, generated by a competition called 'Design for the First World' (Dx1W). It represents, to me, the voice of a new generation as it comes face to face with this inherited narrative of a global developmental hierarchy, the most benevolent version of which proposed that the advanced technological civilizations would uplift the backward ones.

The context was an New York University course assignment of the kind that has become familiar in digital design classes. Technically trained students (usually with no background in global history or political theory) are given an assignment to design a project that will bring the developing world forward into a fuller modernity. The student, Carolina Vallejo, recalls,

Dx1W began as a sarcastic comment. The idea came to me in a class in which I was asked to create an object on 'social design'. The assignment was one week long and there was no specific 
context. Why would you assume that you can design something to solve a problem for the socalled Third World - a world you don't know - in a week? Well, because Bono has told us so. Didn't we all just change the world by going to the Live 8 concerts? ... I decided to do something about it and this is how this competition was born. ${ }^{2}$

She launched a kickstarter competition, Dx1W, explaining, 'perhaps it is time that we, the so-called Third World minds, focused our energy and creativity on solving some of the First World problems'.

News of the tongue-in-cheek competition went viral after Clay Shirky and other prominent digital commentators shared it on Twitter and Facebook. I think that this moment captures the ways in which young peoples' common-sense understandings of modernity today fly in the face of academic models that we inherited from scholarship forged in Cold War and colonialist contexts. I grew up in 'backward' socialist India. And my parents were born in 'British' India. For our generations, the notions that India was stuck in an earlier 'stage' of growth (by economist Walt Rostow's model); that it lagged behind the West in science, technology and development; and that it would always be trying to 'catch up', were naturalized by economic modelling. Yet for Indians who developed a national consciousness in the 1990s, India is not playing catch-up now; it has already emerged; India is everybody's future. ${ }^{3}$

Dx1W works as a clever joke, but it only inverts the contradictions of this legacy. Difficult questions remain for scholars. While design students are savvy enough to question the hierarchies implicit in such an assignment, they nevertheless find themselves in a job market predicated on global consumption, and have limited access to interdisciplinary education in the critical historiographic traditions that might produce alternative technological practices and design futures. How might such students find routes to alternative design thinking? ${ }^{4}$ On the ground in India and China, on the other hand, critical scholarly traditions and public intellectual debates are less central than before, as ambitious young people understandably choose well-remunerated techno-entrepreneurial lifestyles over underpaid humanist writing. What domains will nurture future public intellectuals, and from where will critical voices come? Are Indian planners now grasping at simplistic models of transparent, modern futures, positively revaluing technologically mobile citizens but casting farmers and non-digital workers into a new narrative of backwardness? How might we reimagine an economic history of development that recognizes our non-anglophone, local legacies of imaginative thinking about scientific and technological modes of being? While South Asia's subaltern school and Marxist historians have eloquently critiqued diffusionist models of modernity, they have not really engaged with localized, detailed histories of science and technology. Indian modernity is often narrated via three big 'isms': colonialism, socialism, and free-market capitalism.

2 The original site is inactive, and the author's name has been removed from most remaining traces. A basic Facebook page remains, and the backstory is archived at the Way Back Machine at https:/web.archive.org/ web/20141115015755/http://designforthefirstworld.com/about-2.

3 As Obama said when he visited India during his first term, 'India is not emerging; it has emerged'. Barack Obama, public address, New Delhi, 7 November 2010.

4 One response to this question is in this collaborative paper: Kavita Philip, Lilly Irani and Paul Dourish, 'Postcolonial computing: a tactical survey', Science, Technology \& Human Values (2012) 37, pp. 3-29. 
The turgid models of progress that bedevil Indian economic history and science/tech planning have discouraged creative young scholars from reinvestigating these fields. I think the ideas of alternative, counterfactual or speculative modernities might be useful in dislodging some of these large analytic categories, and in bringing some fresh thinking to the historical and political analysis of Indian science and technology.

Indian technology development was subject to multiple understandings through the second half of the twentieth century, with some redistributive projects attempting to hold back the logic of factory production and commodity expansion, and others, such as the space programme, the atomic energy programme and large dam building, attempting to bring the biggest technology from the industrialized world to the service of the emerging nation. Postcolonial technology might seem to have been defined by a deep schizophrenia, if we read these as paradoxes. But I prefer to read these paradoxes as necessary elements of the heterovalent meanings of technology. The meanings of technology were never fixed in any essentialist or transhistorical sense; its different significations, infrastructures and practices emerged as technology pervaded global politics via the practical design of newly decolonized nations in the late twentieth century. The middle decades of the twentieth century witnessed a global experiment (encompassing former colonies in Africa and Asia) that shaped multiple lived meanings of technology and nationalism. How do we grasp this heterovalency? The best speculative-fiction writers are comfortable with polyvalent meanings and heterotemporal narratives; they approach techno-science as a contextual, cultural form that shapes individual subjectivities, but also as a form of practical knowledge that has instrumental effects in the world. They don't rely on the clichéd binaries (for example, empiricism versus theory, truth versus belief, techne versus poesis) that nationalist, Marxist, and liberal historiography tend to deploy. I find good speculative fiction especially exciting when the standard historiography sends me into dead ends.

Anil: There is, of course, a long tradition of seeing the East/Other as a source of solutions, real and imagined, for Western problems, real and imagined. For example, Andrew Bell's 1789 Madras system of pedagogy inspired by so-called Hindu methods, or Shelley seeing a utopian marital system in the completely imaginary 'Empire of the Nairs', or the excitement in the 1980s over Japanese methods of management. What is new is that this mindset seems to be becoming a part of the tradition in developing countries as well. Projects like Dx1W speak to this new development. It is also literalized in novels like Samit Basu's recent novel Turbulence. ${ }^{5}$ Indeed, in the climactic scene, Basu has Indian superheroes, complete with cape and reinforced underwear, save the city of London from supervillains, also of Indian origin.

But as Kavita says, such inversions also affirm problematic ideas, such as the existence of context-free solutions for social problems or that technological progress is social progress. These problematic ideas haven't gone unchallenged in the speculative literature from developing countries. I am reminded of Vandana Singh's Delhi, whose protagonist simultaneously exists in multiple histories; the rejection of the standard historiography of 
malaria in Amitav Ghosh's The Calcutta Chromosome; and the heterotopias in Rushdie's novels.

That said, the tropes of backwardness and catching up are more often found in outsider/colonial rather than native perspectives. If one thinks in terms of the metaphors that inform these narratives, then it will be seen that Catch-Up and its two siblings Forging-Ahead and Falling-Behind, to use Moses Abramovitz's amusing taxonomy, are derived from the development-is-a-journey conceptual metaphor. Borrowing from Lakoff and Johnson's discussion of the an-argument-is-a-journey conceptual metaphor, we see that it leads to narratives where nations 'set out', are influenced by events that 'point the way', 'follow' other nations and 'get to the next stage', or they can 'founder', or 'take a wrong direction', but with a little luck 'arrive' at various 'goals'. Journeys, of course, can be conducted with various speeds and when there are several travellers, Catch-Up, Forging-Ahead and Falling-Behind become ways of comparing the metaphorical distance covered.

But this is one of those cognitive illusions that language effects. Development-is-ajourney is only one narrative possibility, but I would argue that for nineteenth-century South Asians it is not a very compelling one. Instead, the native perspective, at least in India, revolved around the idea of reform. The logic of reform was (and is) based on a wellness metaphor - development as a cure-all - and therefore of curing a body politic that has gone out of balance. This conceptual framework generates coherent entailments exceedingly familiar to South Asians on account of their long Ayurvedic tradition. Gandhi's merging of the freedom struggle with personal monastic discipline originated from this perspective. It also explains, for example, why Vivekananda, despite his attempt to see India through European eyes, still resorted to a wellnessbased conceptual framework:

Devastation by violent plague and cholera; malaria eating into the very vitals of the nation; starvation and semi-starvation as second nature; death-like famine often dancing its tragic dance; the Kurukshetra [battlefield] of malady and misery, the huge cremation ground, strewn with the dead bones of lost hope, activity, joy, and courage; and in the midst of that, sitting in august silence, the Yogi, absorbed in deep communion with the Spirit, with no other goal in life than Moksha; This is what meets the eye of the European traveller in India.

In short, native conceptualizations of development produce fictional and non-fictional narratives in which India is seen as having gone into a deep sleep, forgotten its past, suffered degeneration, but with the right educational treatment there's every hope the patient could regain vigour, energy and vitality, and rise to face the new dawn.

Anna: Okay, so we have discarded this understanding of development as the simple repetition of processes that have already occurred elsewhere. How does the idea of 'leapfrogging' - so prevalent, for example, with regard to the adoption of the mobile phone (the fastest technology to be adopted worldwide) - help challenge or reinforce assumptions about the time of development?

Jeff: A good place to start a discussion of this kind, at least among those immersed in speculative fiction, is with William Gibson's famous comment that the future is 
'already here' but 'is not evenly distributed'. There are certain kinds of setting that lay claim to more of the 'future' than others, and where things widely perceived as 'futuristic' can be found. From the mid-1800s on, I would argue, these have included International Exhibitions and World's Fairs, which offered both a virtual tour of the world via objects and a sense of times to come via displays of the latest technologies, and global cities, which have been similarly both unusually cosmopolitan and containing new machines. The places that claimed more of 'the future' in the nineteenth century and early 1900s were mostly European capitals, but also American cities, such as Chicago (where the great 1893 World's Fair was held and a tellingly titled 'Century of Progress' sequel exhibition was staged in 1933) and New York (the first metropolis outside Europe to claim top-tier global-city status).

Reflecting a sense of these places as 'futuristic', in either a utopian or dystopian sense, was that novels and then films that offered a sense of how things would be, rather than simply how they were, would often be set explicitly in those same cities or at least evoke them. And when Disney parks, with their 'Tomorrowlands', became part of the global scene, we see similar cities getting them. Whether we follow the thread of international exhibitions, of global cities, of novels and films that seem futuristic, or of Disney theme parks, it seem fair to say that the first Asian locales to come into the picture as competitors with places like London, Paris, Chicago, New York, Berlin and some other places in the West would be Tokyo (the first Asian city to get a Disneyland), Hong Kong (think of films like Ghost in the Shell), and Singapore (which, to refer to Gibson again, the Neuromancer author famously described in Wired as 'Disneyland with the death penalty'). More recently, Shanghai has entered the club of futuristic cities.

This inspires two final thoughts. One is that we have reached a point where morefuturistic-than-thou competitions are sometimes intra-Asian rather than between Asia and the West. When Delhi hosted the Commonwealth Games, for example, the eye-popping, sleekly run mega-event that it was being measured against - and often seen as failing to come close to equalling - was not a European or North American one but the Beijing games. Another is that, when it comes to some dystopian features, Chinese cities can be seen both as moving into uncharted territory and as throwbacks. The level of surveillance and propaganda can have decidedly twenty-first-century aspects, as in the state's ability to issue a text message that goes to every cellphone, but the images of incredibly heavy smog, dubbed portents of an 'airpocalypse', bring to mind those that in earlier periods showed London and then later Los Angeles as unhealthy places to breathe. There is, of course, a mix of the retro and the au courant in some airpocalyse photographs - when they show how hard the smog in Beijing or Shanghai can make it to see clearly a massive video screen perched high up on a state-of-the-art skyscraper. So we have both leapfrogging and novel sorts of combinations of old and new.

Kavita: The emergence of India and China on the world economic stage might simply be thought of as evidence that the developing world has, by dint of hard work and austerity, caught up with the West. But I've also been interested in the notion of leapfrogging - it appears to help explain how we caught up (by a 'workaround', skipping the stages prescribed by Rostow). More radically, it suggests that workarounds, leapfrogs and the ad 
hoc discarding of standard trajectories might be the future of development, confounding the very task of predictive economic modelling.

In addition to the standard models of leapfrogging (state and corporations developing technological infrastructure like cellphone towers, for example, in regions not yet reached by roads and education), I'm interested in non-state, non-corporate, illegal forms of technical practice that have enabled some spectacular leapfrogging, and almost overnight seemed to end a kind of technological and cultural isolation that had maintained a separation between the West and the Rest.

Take film, for example. In May 2007, the Motion Picture Association of America launched three blockbusters on Memorial Day weekend (the start of the US summer movie season). I remember following along as the US press reported minute-by-minute competition between the heroes of the Memorial Day weekend: a drunken pirate, a superhero in a spider suit, and a green monster (Pirates of the Caribbean: At World's End, Spider-Man 3, and Shrek the Third). These annual reports are followed by many, since the US film industry's annual forecast relies strongly on Memorial Day weekend openings.

But I was following for a different reason: Spidey was dogged by stories of pirates. Reuters had reported from Beijing in April that Spider-Man 3 was already being sold on that city's streets. (That report was later contradicted by Sony, who claimed that their investigators had uncovered Spidey 2 in Spidey 3 packaging). Spider-Man 3 opened in China on 3 May, a day before its US opening, partly because of the pressure piracy exerts on the US film industry.

For those of us who recall growing up in India or China, watching an occasional US film opening years after it had faded from US screens, this is no small shift in media circulation. Piracy shapes transnational economies. And, despite the official disavowal of piracy, and the cleaning up of copyright violations in the wake of WTO and TRIPs legislation, everyone privately acknowledges that without piracy we might not have had quite the spread of global consumer culture in India that we have now (a phenomenon that US cultural producers love), nor the rise of the California technological boom, fuelled by immigrant Indian engineers and coders, many of whom got their training, in some significant way, via pirated technologies.

Jeff: I just want to jump in quickly with an aside, before Anil will, I expect, have insightful things to add to Kavita's astute discussion of piracy. As someone who grew up not far from Hollywood, my youth was suffused with viewings of US popular-cultural products as soon as they were available, but I did get to experience via a year in China as a graduate student the sense that Indian and Chinese youths once had of being out of the loop when it came to the circulation of Hollywood films. If memory serves, the only American movie that played in Shanghai during the entire 1986-1987 academic year was Superman, which the Chinese students I knew were very excited about seeing. Starved for popular entertainment of any kind, I would have gone with them to check it out happily, except that it was the version starring Christopher Reeve, which had opened in the US back in the late 1970s. By the time Chinese viewers got their first chance to see it, I had already watched not only that movie but also the Superman II and Superman III sequels, both of which had been released at home before the first one premiered in China. 
Anil: What is change over time, and how can we represent it in something other than linear metaphors? Just as piracy and leapfrogging seem to undermine neat academic models of change, I believe the study of speculative fiction, which includes sci-fi, can question, modify and even subvert our ideas about historical narratives of change over time.

This is an outcome of the process by which SF has often called into question the idea of fiction itself. My interest in the more theoretical aspects of sci-fi began some ten years ago with a minor cognitive rash, as it were, when I realized I didn't know what made a story a sci-fi story. Inclusion into the genre seemed to be based on essentialist rather than prototypical criteria. Or to put it another way, it seemed arbitrary. Thus Lucian of Samosata's interplanetary tale A True Story (second century CE) has been rejected on that ground it doesn't have any science, ${ }^{6}$ Ursula K. Le Guinn and Brian Attebery have been accused of including non-sci-fi stories in their Norton Book of Science Fiction anthology, ${ }^{7}$ and one of the genre's leading writers, Ted Chiang, has commented on how he's often told he doesn't write sci-fi. ${ }^{8}$

This cognitive rash shows little sign of disappearing, but I can offer a tentative model of the genre. Speculative fiction at its best undermines linear narratives - even the idea of storytelling itself because it can question the reasons stories offer. I'm not calling for abandoning stories. Far from it. But I reject the utilitarian explanations often given for why stories are needed. I do not believe we need stories to make us more human, teach us empathy, reveal the eternal verities, help us make sense of the world or give meaning to our lives. I write because I cannot control the reader's response. This in fact is the subject of my novel Half of What I Say and I wrote it because I had no guarantee that readers would see things my way. No writer can control the reader's response. No story can. ${ }^{9}$

Thus stories are possible because this most primitive of freedoms is possible. But the totalitarian can tell stories too. Out of the best of intentions, parents, the first dictators in our lives, teach our minds to mistake comfort for truth, and it is a hard habit to overcome. By using fiction to treat fiction, speculative fiction works in the manner of a homeopathic cure.

Anna: I am interested in how to characterize the contemporary state of science fiction in China and India. At a recent symposium on Chinese Science Fiction held at Duke Kunshan, many of the participants stated that the world of science fiction in China was very small (they guessed around only fifty writers). At the same time, Liu Cixin's recent Hugo award for The Three Body Problem has generated an enormous interest in the genre. One of the most compelling aspects of Liu's novel is how he manages to

6 B.P. Reardon, 'Lucien: a true story', in Reardon (ed.), Collected Ancient Greek Novels, Berkeley: University of California Press, 1989, pp. 619-649.

7 Joseph Miller, 'Popes or tropes: defining the grails of science fiction', in Gary Westfahl and George Slusser (eds.), Science Fiction: Canonization, Marginalization, and the Academy, Westwood, CT: Greenwood Press, 2002, pp. 79-87, 82.

8 Taylor Clark, The Perfectionist, interview with Ted Chiang in California Sunday Magazine, 4 January 2015, available at https://stories.californiasunday.com/2015-01-04/ted-chiang-scifi-perfectionist.

9 Anil Menon, Half of What I Say, New Delhi: Bloomsbury, 2015. 
escape the political allegory of so much other Chinese science fiction and be at once very deterritorialized while also being extremely local (this is particularly evident in the game within the book). Perhaps this is what accounts for the book's strong appeal both within China and abroad?

Jeff: I guess my main response is to wonder what exactly they mean when defining a genre. There is so much interesting writing out there that has some science fiction or fantasy elements. This is partly due to the rise of dystopian works but I think it has often been around. There may be only a small number of writers who, like Liu Cixin, have very strong scientific chops as well as literary ones, but in a broader sense, if we include all works that involve some sorts of imaginative leaps, order the world in ways other than what we are used to in the present, and all writers who have done at least one work with SF elements, we have a pretty big tent now and one that has long been big. There were SF elements in Twain's A Connecticut Yankee in King Arthur's Court, in one of Amitav Ghosh's novels, in George Orwell's 1984 (though he's not always thought of as an SF writer), in The Hunger Games, in Gulliver's Travels, even in a Trollope novel, The Defined Period. In Chinese works, we can go back to a Liang Qichao fragment 'The Future of New China' from 1902, which imagines a future moment when China hosts a World's Fair, Lao She's Cat Country (classic SF construct of life on Mars), and there are even elements of Yu Hua's The Seventh Day that, in having the dead and the living operate in parallel zones, have a feel like certain kinds of social science fiction.

In summer 2015, when I heard that The Three Body Problem had won the Hugo, I wondered, having not read the book, if the prize committee was simply attracted by the idea of celebrating a work from a place where science fiction was on the rise, and there was also a good story in it being translated by a notable Chinese American genre author. Reading it, though, I found I had misjudged things, since it is fascinating on many levels - for the story, for the science, for the social critique, and for the fact that it opens with, of all things, a look back to scientists, among others (including Cat Country author Lao She, who is mentioned slyly in passing), suffering during the Cultural Revolution. It was a surprising book in many ways, both very original and of the moment and fitting in with established international conventions, such as the divided peoples of the world coming together (à la movie Independence Day, along with many earlier Western books and films) to fight an extraterrestrial enemy whose threat to the species makes nationalistic squabbling seem petty.

Anil: This is a complicated question, of course, partly because a genre, to remain a living genre, must elude definition. And the invisibility of non-English-language works in the world of the Hugo and other awards makes it even more difficult to explore the rich histories of speculative fiction in India. In the interest of brevity, let's just consider the vast range of works in English and Bengali that I see as science-fictional. They fall into three kinds: nationalistic, mimetic and, for want of a better term, whimsical. The first work of fiction in English by a South Asian author appeared in the Calcutta Literary Gazette and its author was a young man, Kylas Chundar Dutt, a twenty-two-year-old student at the 
Hindu College. His story, 'A journal of 48 hours of the year 1945', narrated the final days of Mohun Babu, a young nationalist who envisages a free India. Since India won its independence in 1947 , Dutt was only off by a couple of years. Ten years later, K.C. Dutt's brother, Shashi Chunder Dutt, produced a novella, Republic of Orissa: Annals from the Pages of the 20th Century, which imagined a free Indian republic based in Orissa, India.

In these tales, there is no science in the sense of robots or time travel, but judged by subtler criteria such as how time is conceived or the working out of what-if scenarios, these nationalistic stories set in the future are SF in the same sense Orwell's political fables are SF. For reasons of being accessible to local audiences (not to mention avoiding the censor's eye), most of the nationalistic SF stories were written in regional languages.

The second type of Indian SF stories, the mimetic kind, is seen from the 1880s onwards. There were hundreds of Bengali magazines popping in and out of existence like quantum foam, and an insatiable thirst for accessible explanations of scientific developments. Bengali authors didn't lack for outlets and produced dozens of science-based stories inspired by Wells and Verne. So we have stories like Jagdish Chandra Bose's Palotak Toofan (Runaway Typhoon, 1896) which anticipated the butterfly effect from chaos theory, Hemlal Dutta's Rahasya (The Mystery, 1882) and Jagadananda Roy's Shukra Brabman (Journey to Venus) written sometime between 1879 and 1895. Fast-forwarding some hundred years, there's Param Jit Kumar's inadvertently delightful Scourge from the Sky. ${ }^{10}$ The author didn't lack for self-confidence. An earlier masterpiece had predicted the Indo-Chinese war and this volume, modestly self-labelled the 'Greatest Science Fiction of the Century', was an exuberant interstellar adventure complete with flying saucers, aliens, busty women, Nazis, trips to Mars and Jupiter, and because he could, Eternity. Published today and properly packaged, it could win a Hugo.

The third type of Indian SF story is perhaps the most interesting. It is marked by a strain of whimsy that serves to subvert the pretensions of science and technology. In these stories, science, and by extension modernity, is ridiculed and subverted by exaggeration and faux seriousness. Premendra Mitra's Ghana-da stories (1940-1950) fall in this category, as does Surendranath Bandhopadyay's Vigyan Babu (1888). Bandhopadyay's story features a scientist, Makhan Mukhopadyay, who goes around wearing a lightning conductor, has special glasses to detect minute particles in higher education, and does research on topics such as whether it is scientifically feasible to marry a married woman. The whimsical element also informs stories such as Manek Mistry's Stories of the Alien Invasion, in which aliens turn up and want to do nothing other than laugh at humans, and Bibhas Sen's Zero-Sum Game, ${ }^{11}$ in which India demands royalties from the United States for the use of zero ('say at the rate of one cent per thousand zeroes').

10 Param Jit Kumar, Scourge from the Sky, Chandigarh: People's Guardian Publishers, 1964.

11 Manek Mistry, Stories of the Alien Invasion, Abyss \& Apex, 2007, available at www.abyssapexzine. com/archives/abyss-and-apex2007/stories-of-the-alien-invasion; Bibhas Sen, Zero-Sum Game (Katha Prize Stories, 4), New Delhi: Katha Books, 1994, pp. 244-252. 
Of course, these are loose categorizations. For example, Rajshekar 'Parusharam' Basu's Ulat Puran (1924) imagines a Britain colonized by Indians. A more complex example is Girish Chandra Ghose's play Mayabasan (1897), which also features a (mad) scientist but whose darkly funny and melodramatic tone ultimately tends towards a certain despair.

It was such conflicted, defiant, polyphonic responses by South Asians to industrialization, to colonization and to the new material and technological context around them that resulted in a new kind of writing which shares many similarities with Western SF but that are also shaped by local concerns and native literary traditions.

Kavita: As a riff off Anil's wonderful taxonomic exploration of nationalist, mimetic and whimsical science fiction in India, I think it would be interesting to think in the same terms about how we write the history of science.

Early histories of science tended to proceed within national frames. For example, histories of the Scottish Enlightenment, the English Industrial Revolution, French botany, Spanish medical cultures, and so on were key to understanding the ways in which particular sciences emerged and spread. As productive as they were in terms of unearthing specific scientific developments, early nationalist frames promoted implicitly diffusionist assumptions in the larger field-shaping debates. Even sympathetic observers of Indian and Chinese science framed their studies with Eurocentric questions such as the classic Needham problem: why has modern science developed only in Europe, and not in Chinese (or Indian) civilization? ${ }^{12}$

Reactions to these studies emerged from India and China, of course. These studies proved that their own nations had a glorious scientific heritage. They explored, for example, the non-Western origins of scientific insights claimed to be Western; indigenous theorizations of nature and culture; or flows of mathematical knowledge from Chinese, Indian, Arab regions towards the West. Again, this work has significant empirical value. It constitutes a 'mimetic' historiography of science, which was characterized by an uncritical transposition, or a simple inversion, of Euro-nationalist forms of historical argument, and of linear chronological models that understood progress according to the closeness of past knowledge to present scientific truths.

A Whiggish history of science left a transhistorical character called Truth in charge of its narratives, whether Eurocentric or nativist. And the sometimes contentious, often tedious, historiographic oscillation between Western and non-Western nationalist frames has had an unfortunate side effect: the hermetic separation of different nationalist historiographies from each other in the pedagogical realm. Many students trained in the West never came in contact with Indian historiography of science, even when it was available in English. Early historians of science in India like Debiprasad Chattopadhyaya (1918-1993) and Damodar Dharmananda Kosambi (1907-1966) were polymaths, trained in the sciences, writing as historians, and involved in anti-colonial movements. Their histories are fascinating. But neither they nor more recent Indian historians of

12 Joseph Needham et al., Science and Civilisation in China, 25 vols., Cambridge: Cambridge University Press, 1954-2015. 
science like Dhruv Raina, S. Irfan Habib or Abha Sur are included in standard EuroAmerican history-of-science curricula.

As historian of science S. Irfan Habib recently said, 'Modern science is a conglomeration of different cultures and civilisations ... However, you can't replace Eurocentrism with another centrism called Islamic science or Hindu-centrism.' ${ }^{13}$ There's a strong critical thread in Indian historiography of science, involving experimental moves beyond nationalist historiography of science. I hope we'll see the development of an equivalent of what Anil called the 'whimsical' mode. I don't mean a mode of thinking in which standards are abandoned and anything goes; but I do hope for radically interdisciplinary forms of writing that cross the lines among disciplines. After all, our debates about science and technology already draw inspiration from history, anthropology, philosophy, politics and journalism. It's counterintuitive to shift away from a teleological allegiance to the idea of a transhistorical Truth and toward a dialogic style that engages with possible futures as well as a multivalent present and a contingent past. But this move has already begun, as we see from recent work with titles like 'Future's past' and 'Telling histories of the future.'14

As Anil said about 'whimsical' speculative fiction, at its best it creatively undermines linear narratives while asking a meta-question: what makes a study a 'history of science', rather than any other kind of 'history', or indeed, any disciplinary inquiry? Does its topic have to be recognizably scientific? Must it exclude belief, ritual, fiction or magic? At its best, this whimsical mode calls into question the very idea of historical writing, the idea of an academic discipline complete unto itself. I don't say this in some nihilistic sense of abolishing disciplinary rigour; I say this because it describes, historically, what many Indian historians of science already do. Asking questions about the politics of science, engaging with social movements, shaping policy and teaching outside traditional institutions, even while doing archival research and producing scholarly work: there is a syncretism in method that characterizes the most interesting history of science in India. And yet the figures I find most fascinating (D.D. Kosambi and his ilk) are often regarded as not really historians of science, just as Ted Chiang is often told he doesn't really write science fiction. So to me, this 'whimsical' mode might be a radically interdisciplinary, dialogic, transnational historiography of science that subverts the colonial mythologies of the Enlightenment while recognizing that the magic of science genuinely gripped Westerners and non-Westerners alike; that subverts a Whiggish historiography while embracing the need to build empirically based yet speculatively bold new historiographic models for the history of science.

13 S. Irfan Habib, 'Modern science can be pursued by any believer', interview by Rakhi Chakrabarty, Times of India, 2 November 2012, available at http://timesofindia.indiatimes.com/edit-page/S-Irfan-Habib-Modernscience-can-be-pursued-by-any-believer/articleshow/17052707.cms.

14 See Manan Ahmed, 'Future's past', in Adil Najam and Moeed Yusuf (eds.), South Asia 2060, London: Anthem Press, 2013; Kavita Philip, 'Telling histories of the future: the imaginaries of Indian technoscience', in Ravinder Kaur and Thomas Blom Hansen, eds., Identities (2016) 23(3), special issue, Aesthetics of Arrival: Spectacle, Capital, Novelty in Post-reform India, pp. 276-293, available at http://dx.doi.org/10.1080/ 1070289X.2015.1034129. 
Anna: One of the most striking elements of cyberculture in both India and China is a kind of indigenous hacker/DIY ethos. Today there is a widespread embrace of a global 'maker' culture that differs from, but is connected to, this hacker/DIY approach. How does an emphasis on hacking/making impact narratives of science and science fiction in India and China?

Kavita: There's a lot going on with all kinds of making and hacking in India, at the level of the state as well as of individual citizens. Soon after he was elected to power in 2014, Indian prime minister Narendra Modi started a campaign called 'Make in India', focusing citizens' attention on the need for manufacturing innovation and entrepreneurial technologists in India's bid to shape the future. He has also been seen as India's futurist science and tech-booster leader, spearheading a global media blitz celebrating the indigenously designed Mars mission, and enthusiastically disseminating everyday opinions on governance to the Twitter-verse (supported by a social-media team that continually scours the Internet for critiques of India's aggressive new global style and its Hindu nationalist leadership). At the 'grass-roots coder' end of the spectrum, Indian tech circles have, like Silicon Valley, profited from a tradition of hackathons and bar-camps, in which software developers devote weekends and evenings to improving their coding skills and developing new technologies. The make/hack revolution, in addition to being a clever response to the historical complaint that colonialism destroyed indigenous Indian manufacturing, today funnels huge amounts of free labour into what used to be called continuing education and training (something that the state and corporations once had to pay for).

Scholars trained in computation as well as in ethnography are beginning to analyse hacking and making in the context of the decline of US manufacturing; the globalization and modularization of production; and flexible, mobile subjectivities of creation. ${ }^{15} \mathrm{We}$ can now understand the celebration of makers and hackers in terms of an analytical shift away from traditional categories of production relations, labour rights and so on. Labour histories used to be studied far away from those who talk about computer-supported collaborative work, but with these new questions come opportunities to talk across these old boundaries. Here, I think, speculative-fiction writers have an advantage: they're used to making fiction out of impure mixtures.

As trained historians, we're accustomed to thinking that good scholarship grows out of disciplined, systematic investigation. We know that history doesn't really happen in neat categories, but we find the categories useful in sorting books into their proper place. As readers or teachers, we need to put material in library catalogues, or choose course topics and titles. As researchers, we must select which archival collections to study. Choosing to read the archive of Revenue reports would give us a different picture from the archives of religious institutions; a state's record of elections gives us

15 See, for example, Silvia Lindtner, 'Hacking with Chinese characteristics: the promises of the maker movement against China's manufacturing culture', Science, Technology \& Human Values (2015) 40, pp. 854-879; Lilly Irani, 'Hackathons and the making of entrepreneurial citizenship', Science, Technology o Human Values (2015) 40, pp. 799-824. 
a different history than does the same state's science policy reports. Reading all archives is our impossible dream; the historian must choose.

Indian politics is, like any other, full of impure mixtures. The politics of nation, gender, religion, science and technology have never been available to the historian in pure categories. Yet scholars have been accustomed, in our habits of research and analysis, to look, sort and disseminate in ways that naturalize the 'sorting out' of historical trends into the political, the religious, the scientific and so on - this is what we mean by disciplined, systematic research. As research accumulates in disciplined minds, a kind of catachresis occurs: metaphors of the world take root in our analytic imaginations as we find their formal categories expedient, convenient, useful and productive; soon, the world itself seems to emerge in these forms.

We see the world in the form of our disciplinary imaginations, but speculative fiction helps us see it through the impure categories in which most people experience the world. It's interesting to think about what technology policy and economic planning would look like if the studies that informed them were shaped by speculative fiction and interdisciplinary practice, rather than purely by disciplinary knowledge.

Anil: Ever since I read Doctorow's Makers, I've been curious about what a non-Western hacker culture might look like. The hacker is a hero figure in recent Western works, a marginal figure who decentres the existing order through objects that represent that order. But what kind of order? Typically it is the capitalist order, specifically property rights, and the security apparatus that guards it. There is a certain frisson generated by narratives that describe, say, how a bright high-school kid broke into the Pentagon or how government hackers destroyed Iran's nuclear centrifuges. How clever! How daring! How illegal! We too could be such daredevils if only we had a better grasp of logarithms and the guarantee of a presidential pardon.

This type of hacking doesn't interest me much. Instead of order-breaking, can we conceive of a modality which expands and creates new kinds of order? Fortunately, we can. It's called art.

Picasso took an old bicycle's handlebar and seat, welded the handlebar upside down to the base of the seat, and a bull's head was born. Today, we may adore this exemplar of found art for the elegant expression of wit and whimsy it is, but in 1944, when it was first exhibited at the Salon d'automne, Picasso's hacking provoked a public demonstration from the upstanding citizens of Paris. The installation had to be taken down.

What capitalist order had he broken? None. The bicycle was junk and the French have no laws against rearranging one's junk. But the answer is obvious, of course. Picasso had created a new aesthetic order. He had rearranged the human imagination, so to speak. That is always upsetting.

Lorraine Daston has detailed how imagination and science have had a contentious partnership over the last few centuries. ${ }^{16}$ One only has to reflect on the scarcity of poetry, of art, and the sober objective styles enforced in contemporary research journals to see that flights of imagination continue to be somewhat suspect. This is also true of

16 Lorraine Daston, 'Fear and loathing of the imagination in science', Daedalus (1998) 127, pp. 73-95. 
technology. Except for a perverse few, most of us would be afraid of toasters determined to dream.

In short, I am thinking of hackers who have little interest in order-breaking. They are artists who are not always aware that they are artists. The housewife hacker, the sadbu hacker, the idol-makers of Kolkata's Durga puja, entirely ordinary figures who don't represent either end of a dichotomy of haves and have-nots, but instead are part and parcel of a social quilt. This kind of hacking is more like quilting, like jugaad, like bower bird nest building, like culture making, like facts rearranged upside down to become fictions. No act of imagination is without risk and decentring is inevitable. So there will always be the temptation to turn these acts into heroic tales, as Picasso's act is sometimes narrated these days. So these hackers may be used to tell all the usual stories, but these stories are not why they do what they do. They aren't unlike Yeats's pilot, doomed to play heroic roles in other people's conflicts, but who flies simply for 'the lonely impulse of delight'.

Anna: In the same week in October 2015, India's and China's heads of state met with Facebook CEO Mark Zuckerberg. How do you read the symbolic, economic and strategic significance of that moment?

Jeff: The effort Zuckerberg made to cosy up to Xi struck me as surreal - even before the bizarre story began circulating that he had asked the Communist Party head to select a Chinese name for his unborn child. What I mused on in a commentary for Dissent at the time was the irony of the head of Facebook, a company whose main product is banned on the Chinese mainland, pandering to the head of the organization that keeps it verboten, while leaders of the Hong Kong protests of 2014 were in the US trying to draw attention to their cause on the first anniversary of its start. One way the Beijing authorities have punished the young activists who led that inspiring struggle to maintain the degrees of greater freedom found in Hong Kong has been to ban them from travelling to the mainland. If, I asked in that piece, Zuckerberg is determined to please Beijing, and if, as seems likely, he hopes someday Facebook's Hong Kong office will be useful as a staging ground for a move across the border into the massive market nearby, would he consider hiring Joshua Wong or another protest leader, should they apply for a job with his company? How curious is it that a company banned by Beijing would not want to hire someone because he or she, while having all the other attributes of a perfect Facebook employee, was, well, banned by Beijing.

Kavita: The literal meaning of this moment is that Zuckerberg, like Google CEO Sunder Pichai and every other tech company exec, saw these meetings as potential access gates to the world's 'bottom billion', a population that embodies untold riches waiting to be tapped by the first intrepid explorers. In the Indian case, the promise of monumental consumption expenditures in the future is combined with access, in the present, to a highly skilled software development and data service labour force, who can be hired to do global-quality work at a fraction of the cost of the equivalent worker in Silicon Valley. Tech companies want to be in this mix and they are agnostic/pragmatic with respect to politics; they will cosy up to whoever happens to be in power. It just so happens - and we can't blame Zuckerberg for this - that in 2014 the world's largest 
democracy voted into power a self-made populist leader groomed by parties with fascist leanings. ${ }^{17}$ This leads to some bizarre high-profile handshakes, but it's business as usual for the makers of our future. The future just arrives sooner in Palo Alto. ${ }^{18}$

Silicon Valley lies in California's 17th Congressional District, one of only two Asianmajority districts in the US. ${ }^{19}$ There's a Hindu-majority Indian diaspora that professes loyalty to Narendra Modi despite the involvement of his political party and its allies with violent anti-Muslim politics in India, an old practice that gained strength with the global War on Terror and the rise of 'Islamophobia' in the US. The Hindu American Foundation, one of the groups they've formed, seeks a way to counter what they see as the negative influence, in the US, of the diverse diasporic South Asian communities, including Muslims, Christians, Zoroastrians and Jews, that have produced corporate leaders and working-class organizers, progressive intellectuals and queer activists. We're seeing a complicated political legacy take on new forms, which, of course, is nothing new in history. What's new for many is the rhetoric of pragmatism, transparency and efficacy in which technology's future is narrated. Technology seems to many to offer a short cut around the historical problems of racism, sexism and inequality, to a future in which every citizen is, in principle, identically represented by the same kinds of biometrics, and is invited to participate in a sensational range of consumer pleasures. Who could be against that future?

Anil: Actually, watching Zuckerberg's well-scrubbed, fresh-faced and healthy persona, I was reminded of the Pears Soap 'Lightening the White Man's Burden' advertisement. ${ }^{20}$

17 There were reasons to celebrate the democratic impulses of a nation as it rejected the dynastic, uppercaste and elite but professedly secular Congress Party that had ruled the nation with a mixture of vanguardist elitism and democratic liberalism for most of its first half-century. But historians have documented the disturbing proto-fascist roots of the new populism that has taken charge; see, for example, Tapan Basu, Pradip Datta, Tanika Sarkar, Sumit Sarkar and Sambuddha Sen, Khakhi Shorts and Saffron Flags: A Critique of the Hindu Right (Tracts for the Times 2), Hyderabad: Orient Longman, 1992; and Benjamin Zachariah, 'A voluntary Gleischschaltung? Indian perspectives towards a non-Eurocentric understanding of fascism', Transcultural Studies (2014) 2, pp. 63-100.

18 Anthropologist Lucy Suchman recalls hearing this in 1995, said by 'a Silicon Valley technologist' on National Public Radio in Palo Alto: 'The future arrives sooner here.' Suchman describes her own shocked reaction, 'a bodily resistance to being hailed into this claim to the vanguard, with its attendant mandate to enact the future that others will subsequently live'. The opposite reaction appears to shape the ecstatic embrace of their place in the vanguard of global technological progress on the part of Hindu Americans who identify with Modi, and see this moment as part of their long-deserved destiny. Lucy Suchman, 'Anthropological relocations and the limits of design', Annual Review of Anthropology (2011) 40, pp. 1-18.

19 The district was represented by Mike Honda, a liberal Asian American democrat, born to sharecroppers, and interned with his family in a Japanese internment camp in 1942. California journalists reported that diasporic Hindu American organizations (and their Political Action Committee) had raised funds and campaigned to unseat him, and to support candidates more sympathetic to the Republican agenda in the US, and to the Bharatiya Janata Party in India. For an account of how the politics of the Tea Party and Hindutva, diaspora and homeland, are deeply intertwined see, for example, Yasha Levine, 'Ruh Ro: how the Valley's favorite politician may be foiled by a Hindu supremacist banned from the US', available at https:/pando.com/2014/05/29/ruh-ro-how-the-valleys-favorite-politician-may-be-foiled-by-a-hindu-supremacistbanned-from-the-us, 29 May 2014, accessed 1 October 2015.

20 McClure's Magazine, October 1889. In Britain, the Pears Company focused on advertisements that promised to keep fair skins fair, but the year the advertisement ran in the United States, Admiral George 
The soap was to lighten the burden by promoting the virtue of cleanliness in the 'darkest corners of the earth'. Zuckerberg too comes bearing ostensibly pure and transparent soap, except that here the inveiglement is free connectivity for the masses. I suppose godliness, or the singularity, as digital millennialists like to call it, is sure to follow.

Kant warned us that out of humanity's crooked timber, nothing linear was ever made. We still excuse our artefacts on the grounds that they are not responsible for how they are used. The best that can be said for this naive and dangerous view is that it reflects our innocence as a tool-making species. But we have come to childhood's end and are now capable of building terrible tools. For all its gifts, the technology behind digital connectivity also embeds the crookedness of the security establishment that encourages it, the neoliberal capitalism that distributes it, and the state that defends it. The Internet's most cherished ideal is that of giving everyone a voice. That is of little use if the crookedness in its tools also leaves the world at the mercy of regimes that hear everything.

For me, the question to ask about these meetings is the same as the one economist John Hobson asked about nineteenth-century imperialism: cui bono? Who benefits? I think his answer remains valid today. Zuckerberg didn't meet the heads of state of two large and powerful nations. The shareholders behind Facebook met the investors behind these heads of state. If financial interests had not been at stake, the meeting would have never taken place. Facebook needs new worlds filled with people to save, just as nineteenth-century corporations needed people to save.

Of course this is only a hypothesis, not an argument. But as Mark Twain apparently never said, history may not repeat itself, but it definitely rhymes. The Pears advertisement was already obsolete in its time. By 1899 , the Western imperialist adventure, in its pithhelmet form, had begun to wind down. Today, Hindustan Lever owns Pears Soap Company and the burden of enabling civilization has shifted to Sewri, Mumbai. Perhaps so too for the burden of spreading connectivity.

Dewey, who is featured as the burdened white man, had sunk the Spanish fleet in Manila Bay and imperialist enthusiasm in the US was at an all-time high. 